https://doi.org/10.5817/OS2018-3-6

\title{
Proběhl již IV. ročník konference Hodnoty v literatuře a umění
}

Ve dnech 29.-30. srpna 2018 proběhla mezinárodní konference Hodnoty v literatuře a umění konaná s dvouletou periodicitou, a jelikož hovoříme o již IV. ročníku tohoto vědeckého setkání, můžeme událost považovat za tradiční a etablovaný počin Ústavu slavistiky FF MU, který konference pořádá v úzké spolupráci s Českou asociací slavistů. Hlavou veškeré organizace byl profesor Josef Dohnal, který konferenci slavnostně zahájil a rovněž vystoupil s přednáškou v rámci tematického bloku, zaměřeného na tvorbu ruského spisovatele V. M. Garšina. Na zahájení promluvili také profesor Ivo Pospíšil, vedoucí Ústavu slavistiky, a docentka Jana Horáková, proděkanka Filozofické fakulty. Patronát nad konferencí převzali rektor Masarykovy univerzity doc. Mikuláš Bek a děkan Filozofické fakulty prof. Milan Pol.

Téma hodnot bylo $\mathrm{v}$ tomto roce představeno $\mathrm{v}$ devíti blocích, přičemž nejvíce pozornosti bylo upřeno na čtyři hlavní témata a jejich souvislost s hodnotami; přednášející se v nich věnovali občanské válce v Rusku v letech 1918-1922, literární kritice 19. století a také tvorbě dvou významných ruských spisovatelů 19. století, Ivana Sergejeviče Turgeněva a již zmíněného Vsevoloda Michajloviče Garšina.

Ve zbývajících tematických blocích se polem pro zkoumání hodnot stala ruská i světová literatura nejen dnes již klasického 19. století, ale také moderní, experimentální tvorba. Široké spektrum př́íspěvků bylo zaměřeno transdiciplinárně, sféra literatury byla propojena s lingvistikou, pedagogikou, filosofií a literární kritikou. Mezi tématy nechyběl ani širší (kulturologický, historický) či obecnější (filosofický) pohled na hodnoty, např. v příspěvku profesora M. Mikuláška, který se věnoval exegetickým tradicím Východu a Západu.

Pořádající Ústav slavistiky byl na konferenci četně zastoupen, kromě profesora Dohnala vystoupil s příspěvkem profesor Ivo Pospíšil, jeho příspěvek se věnoval axiologii v hraničních literárních žánrech, doktorka Polina Zolina představila stálost, či spíše nestálost hodnot v románu Matušinưv př́pad současného ruského autora Olega Pavlova. Své příspěvky, věnované současníkům Solovjovovi a Dostojevskému, přednesly také docentka Simona Koryčánková a doktorka Lenka Paučová, zástupkyně Katedry ruského jazyka a literatury Pedagogické fakulty MU.

Partnerskou Univerzitu N.I. Lobačevského v Nižním Novgorodu reprezentoval L. Ju. Bolšuchin, který hovořil o románech G. N. Vladimova o Velké vlastenecké válce $\mathrm{v}$ kontextu válečné literatury. Zabýval se otázkou, proč je dílo Vladimova jedním z posledních rozsáhlých románů o válce a z jakého důvodu se o tomto tématu přestávají psát romány. Dílo Vladimova, které vycházelo v období hluboké ekonomické krize před 
rozpadem SSSR, přináší provokativní pohled na tradiční sovětské hodnoty a ukazuje je v novém světle.

Transdiciplinární př́stup k původně literárním a jazykovědným otázkám ukázala ve svém příspěvku Z. A. Kravčenko (Moskva), v jejímž referátu se tvorba M. A. Bulgakova propojila s divadelní vědou. Na př́kladu inscenací dvou různých Bulgakovových her, které se hrály v Moskvě a v Sankt Petěrburgu, poukázala autorka př́spěvku na odlišné př́stupy k divadelnímu umění ve vztahu k originálnímu textu.

Téma přednesu literárního díla na prknech jeviště se částečně promítlo i do prríspěvku O.N. Bojcovové (Moskva), která vznesla otázku vzniku nového literárně-divadelního žánru художественное слово. Její příspěvek na dvou odlišných prrístupech $\mathrm{k}$ uměleckému čtení pro publikum mapoval historický vývoj tohoto žánru od 2o. let minulého století a také nelehké osudy prvních průkopníků v ruském prostředí.

Aktuální téma odrazu literatury ve filmu se objevilo v př́spěvku N. Njagolové (Veliko Tarnovo), věnovaném dramatu Bulgakova Dny Turbinových. Film V. Basova z roku 1976 odpovídá trendu sovětské kinematografie 70. let, kdy se přestalo náboženství a duchovno zobrazovat jako největší nepřítel lidu. Autorka příspěvku představila jemné náznaky lyričnosti, které si režisér díky těmto změnám mohl dovolit.

Přednášející se věnovali nejen ruské literatuře, ale také literaturám dalších zemí. Např́klad A. Gorodecká představila kromě ruské avantgardy také avantgardu nizozemskou a M. Pešková ukázala nový pohled na Rusko, když jej nazírala prizmatem románů českého autora Jáchyma Topola.

Posluchači si mohli vyslechnout tyto a mnohé další zajímavé přednášky, pro jejichž podrobnější zachycení není v krátké zprávě, bohužel, dost prostoru. Někteří zájemci se účastnili konference také absenčně, zasláním př́spěvku do sborníku. Můžeme se tedy těšit na jejich články, které umožní zpř́śstupnit i to, co přímo na konferenci nemohlo zaznít.

Na závěr můžeme s radostí konstatovat, že účast na konferenci byla hojná a že označení konference za „mezinárodni“ bylo zasloužené. Na konferenci bylo př́tomno více než 60 účastníků z 33 měst z 12 zemí: z České republiky, Slovenska, Polska, Madarska, Bulharska, Ukrajiny, Ruska, Běloruska, Gruzie, Kazachstánu, Německa a Izraele. Mezi konferenčními jazyky sice převládala ruština, na programu byly však i přednášky v češtině, slovenštině, polštině a angličtině, přičemž bychom rádi vyzdvihli snahy mnohých přednášejících doplnit svůj výklad prezentací v dalším jazyce či dokonce prezentací dvojjazyčnou, což usnadnilo vzájemné porozumění.

Gratulujeme organizátorům ke zdařilému ročníku konference a těšíme se zase za dva roky na stejně inspirativní setkání.

Dagmar Vysloužilová - Markéta Poledníková 